\title{
VOLATILITAS DAN TRANSMISI HARGA DAGING SAPI DI INDONESIA: STUDI KASUS DI JAKARTA, BANDUNG, SEMARANG DAN SURABAYA
}

\author{
Price Volatility and Transmission of Beef in Indonesia: Case Studies in \\ Jakarta, Bandung, Semarang and Surabaya
}

\author{
Komalawati $^{1^{*}}$, Ratna W. Asmarantaka ${ }^{2}$, Rita Nurmalina ${ }^{2}$, Dedi Budiman Hakim ${ }^{3}$ \\ ${ }^{1}$ BPTP Jawa Tengah, Jl. Soekarno Hatta KM.26 No.10, Tegalsari, Bergas Lor, Bergas, Sikunir, \\ Kabupaten Semarang, Jawa Tengah, 50552, Indonesia \\ ${ }^{2}$ Departemen Agribisnis, Fakultas Ekonomi dan Manajemen Institut Pertanian Bogor, \\ Kampus IPB Dramaga, Bogor, Jawa Barat 16880, Indonesia \\ ${ }^{3}$ Departemen IImu Ekonomi, Fakultas Ekonomi dan Manajemen Institut Pertanian Bogor Kampus IPB \\ Dramaga, Bogor, Jawa Barat 16880, Indonesia \\ Email: lalabptpjtg@gmail.com
}

Naskah diterima: 17/09/2020; Naskah direvisi: 11/06/2021; Disetujui diterbitkan: 16/06/2021; Dipublikasikan online: 15/07/2021

\begin{abstract}
Abstrak
Daging sapi merupakan salah satu komoditas strategis dengan harga yang cukup berfluktuasi. Fluktuasi harga daging sapi dapat berpengaruh terhadap produsen, konsumen, dan industri pengolahan daging sapi skala kecil. Besarnya perubahan harga daging sapi yang terjadi di suatu pasar dapat memengaruhi pasar lainnya dan dapat digunakan untuk mengetahui kekuatan suatu pasar. Kajian ini bertujuan untuk mengkaji volatilitas dan transmisi harga daging sapi di sentra konsumen Jakarta dan sentra produsen Bandung, Semarang dan Surabaya. Data yang digunakan adalah data harian daging sapi. Volatilitas harga harian daging sapi dianalisis dengan menggunakan model GARCH dan transmisi harga dikaji dengan menggunakan model VAR/VECM. Hasil kajian menunjukkan bahwa hanya harga daging sapi Jakarta yang memiliki volatilitas rendah namun persisten dalam jangka panjang. Perubahan harga daging sapi ditransmisikan dua arah dari Jakarta ke Bandung dan Semarang, dan hanya searah dari Jakarta ke Surabaya. Hasil analisis menunjukkan bahwa upaya stabilisasi harga daging sapi dapat dilakukan dengan menjaga ketersediaan daging sapi baik melalui impor (jangka pendek dan menengah) maupun upaya penyediaan bibit sapi dan sapi potong lokal dalam jangka panjang. Iklim usaha daging sapi yang kompetitif juga diperlukan agar ketidaksesuaian perubahan harga antar pasar dapat dikurangi.
\end{abstract}

Kata Kunci: Daging Sapi, Volatilitas, GARCH, Vector Auto Regression, Stabilisasi Harga

\begin{abstract}
Beef is one of the strategic commodities with fairly fluctuating prices. Fluctuations in beef prices could affect producers, consumers, and small-scale beef processing industries. The magnitude of changes in beef prices that occur in a market could affect other markets and could be used to determine the strength of a market. The purpose of this paper is to examine the volatility and transmission of beef prices in the consumer centers of Jakarta and the production centers of Bandung, Semarang and Surabaya. The data used is the daily data of beef. Daily price volatility of beef was analyzed using the GARCH model and price transmission was assessed using the VAR/VECM model. The results of the study show that only Jakarta beef prices have low volatility but are persistent in the long term. Changes in beef prices are transmitted in two directions from Jakarta to Bandung and Semarang, and only in one direction from Jakarta to Surabaya. The results of the analysis show that efforts to stabilize beef prices could be carried out by maintaining the availability of beef either through import (short and medium term) or efforts to provide cattle seeds and local beef cattle in the long term. A competitive beef business climate is also needed so that discrepancies in price changes between markets could be reduced.
\end{abstract}


Keywords: Beef, Volatility, GARCH, Vector Auto Regression, Price Stabilisation

JEL Classification: F12, F13, F15

PENDAHULUAN

Stabilisasi harga pangan masih menjadi isu yang strategis bagi bangsa Indonesia. Hal ini wajar saja mengingat sebagian besar pengeluaran masyarakat Indonesia masih digunakan untuk pangan. Sebagai ilustrasi, pada periode tahun 2018 hingga 2020, penduduk Indonesia secara umum masih memiliki pangsa pengeluaran untuk pangan rata-rata sebesar $49,22 \%$ atau hampir separuh dari pendapatannya (BPS, 2020). Jika dibandingkan antara daerah perdesaan dan perkotaan pada periode yang sama, daerah perdesaan memiliki rata-rata pangsa pengeluaran untuk pangan yang lebih besar $(55,49 \%)$ dari daerah perkotaan (46,05\%) (BPS, 2020). Menurut hukum Engle, pangsa pengeluaran untuk pangan akan semakin menurun dengan semakin meningkatnya tingkat pendapatan (Nicholson, 1995). Dengan tingginya pangsa pengeluaran untuk pangan menyebabkan penduduk Indonesia menjadi sangat rentan terhadap berbagai perubahan atau fluktuasi harga komoditi pangan, terutama bagi penduduk di daerah perdesaan yang hidup dalam garis kemiskinan.
Selain dampaknya terhadap penduduk sebagai konsumen pangan, ketidakpastian harga juga memiliki dampak yang tidak baik bagi produsen pangan, baik skala usaha besar maupun kecil. Ketidakpastian harga dapat memengaruhi petani skala usaha kecil yang menggantungkan sepenuhnya pendapatan dari hasil usahatani dan memiliki keterbatasan kemampuan untuk menunda penjualan hasil pertaniannya (Ceballos et al., 2016). Harga pangan yang tidak stabil juga dapat menghambat berkembangnya investasi di sektor pertanian dan menurunkan pertumbuhan produktivitas pertanian, terutama bagi sektor pertanian yang tidak memiliki manajemen resiko yang baik (Ceballos et al., 2016). Dengan demikian, ketidakpastian harga dapat berdampak luas terhadap peningkatan kemiskinan dan terhambatnya pertumbuhan ekonomi.

Daging sapi merupakan salah satu komoditas pangan yang strategis. Daging sapi diminati oleh masyarakat Indonesia seiring dengan berubahnya pola konsumsi dan selera masyarakat serta kesadaran masyarakat akan pentingnya protein hewani bagi 
pertumbuhan. Perubahan pola konsumsi dan selera masyarakat tersebut telah menempatkan daging sapi di posisi kedua setelah daging unggas dalam memenuhi kebutuhan protein hewani masyarakat Indonesia (Rusdiana \& Maesya, 2017).

Seiring dengan meningkatnya jumlah penduduk Indonesia, permintaan akan daging sapi pun terus mengalami peningkatan. Konsumsi daging sapi di tingkat rumah tangga cenderung mengalami peningkatan dari tahun 2016 hingga 2020 dengan pertumbuhan $3,98 \%$ per tahun. Sementara itu, produksi daging sapi Indonesia pada periode tahun yang sama hanya mengalami peningkatan 0,41\% per tahun (PDSI Pertanian, 2020). Dengan demikian, permintaan daging sapi di Indonesia tidak dapat dipenuhi sepenuhnya dari produksi dalam negeri. Tingginya permintaan daging sapi dibandingkan dengan ketersediaannya telah mendorong terjadinya peningkatan harga daging sapi dalam negeri.

Guna memenuhi kebutuhan dan stabilisasi harga daging sapi dalam negeri, pemerintah melakukan upaya impor daging sapi. Dalam 10 tahun terakhir, impor daging sapi Indonesia terus mengalami peningkatan rata-rata

sebesar $24 \%$, dengan volume impor tertinggi pada tahun 2019 mencapai 266,45 ribu ton atau setara dengan USD 851,09 juta (PDSI Pertanian, 2020). Peningkatan impor tersebut menunjukkan bahwa Indonesia memiliki ketergantungan yang cukup tinggi terhadap impor, sehingga dikhawatirkan bahwa ketersediaan dan harga daging sapi Indonesia menjadi rentan terhadap berbagai perubahan kebijakan serta nilai tukar dan harga daging sapi di pasar internasional. Hasil penelitian Zainuddin et.al. (2015a) menunjukkan adanya integrasi harga daging sapi antara pasar domestik dan dunia yang berimplikasi terhadap stabilitas harga daging sapi domestik yang dipengaruhi oleh stabilitas harga daging sapi di pasar dunia.

Data dari PDSI Pertanian (2020) menyatakan bahwa harga daging sapi di tingkat konsumen terus mengalami peningkatan dengan rata-rata 2,92\% per tahun dari tahun 2016 hingga 2020. Peningkatan tertinggi terjadi pada tahun 2016 yang meningkat $8,84 \%$ dari tahun 2015, sedangkan pada tahun 20192020, harga daging sapi cenderung stabil. Fakta di lapangan menunjukkan bahwa peningkatan harga yang terjadi di pasar daging sapi cenderung terus meningkat dengan perubahan yang sulit 
untuk diprediksi walaupun impor daging sapi telah dilakukan oleh pemerintah. Tidak berpengaruhnya impor daging sapi dalam menurunkan harga daging sapi dalam negeri disebabkan adanya preferensi masyarakat Indonesia yang lebih tertarik pada daging sapi segar.

Adanya peningkatan harga daging sapi yang terus menerus dan sulit diprediksi mengindikasikan adanya kecenderungan harga yang berfluktuasi atau volatil. Volatilitas merujuk kepada kondisi yang tidak stabil, bervariasi dan sulit untuk diprediksi (Dewi et al., 2017). Volatilitas atau fluktuasi harga yang tidak menentu dapat dihitung dengan menggunakan deviasi, standar deviasi dan koefisien variasi (Dewi et al., 2017) hingga menggunakan model ARCH/GARCH model yang diperkenalkan oleh Bollerslev dan Engle (Juanda \& Junaidi, 2012).

Berbagai hasil penelitian sebelumnya (Burhani et.al., 2013; Dewi et.al., 2017; Komalawati et.al,. 2018; 2019) telah mengkaji volatilitas harga daging sapi di pasar domestik Indonesia dengan menggunakan model ARCH/ GARCH. Hasil kajian beberapa peneliti tersebut menunjukkan bahwa harga daging sapi domestik dari tahun 2003 hingga 2013, 2006 hingga 2013, serta 2008 hingga 2016 cenderung volatil atau berfluktuasi dengan tingkat fluktuasi yang cenderung rendah dan persisten dalam jangka panjang. Hasil penelitian lainnya (Pipit et al., 2019; Firmansyah et al., 2021) juga mengkaji volatilitas harga daging sapi secara spesifik di Kepulauan Bangka Belitung dan Kota Jambi dengan menggunakan data harga tahun 2007 hingga 2016 dan 2020 dengan model ARCH/GARCH. Kedua hasil penelitian tersebut juga menghasilkan kesimpulan yang sama yaitu adanya volatilitas harga daging sapi di kedua lokasi tersebut.

Besarnya perubahan harga yang tidak menentu baik dalam jangka pendek maupun jangka panjang di suatu pasar dapat memengaruhi pasar lainnya atau pasar produsen dan produk turunannya. Respon penyesuaian perubahan harga di suatu pasar akibat perubahan harga di pasar lainnya dapat diketahui dengan menggunakan analisis transmisi harga (Miftahuljanah et al., 2020). Selain digunakan untuk mengidentifikasi proses penyesuaian perubahan harga di suatu pasar, analisis transmisi harga juga digunakan untuk mengidentifikasi adanya kekuatan pasar (market power) akibat adanya konsentrasi pasar pada tingkatan yang lebih tinggi dalam suatu rantai pasok (Sukmawati, 2017). 
Salah satu metode yang biasanya digunakan untuk mengetahui transmisi harga atau proses penyesuaian harga daging sapi di suatu pasar akibat perubahan harga daging sapi di pasar lainnya adalah model Vector Error Correction Model (VECM). Beberapa hasil penelitian sebelumnya telah menggunakan metode VECM untuk mengukur transmisi harga daging sapi antar pasar yang berbeda di beberapa provinsi (Zainuddin et al., 2015a; Yusufadisyukur et al., 2020; Septiyarini et al., 2020). Zainuddin et al. (2015a) melalui hasil kajiannya menunjukkan bahwa pasar daging sapi domestik dan dunia terintegrasi dalam jangka panjang dan pendek. Septiyarini et al. (2020) dengan penelitiannya yang mengkaji tentang transmisi harga daging sapi dengan menggunakan model VECM menunjukkan tidak adanya integrasi antara kedua pasar daging sapi di Pontianak. Sementara itu, Yusufadisyukur et al. (2020) mengkaji tentang transmisi harga daging pada pasar di dua provinsi yang berada dalam pulau dan di luar pulau. Dengan menggunakan model VECM, hasil penelitian Yusufadisyukur et al. (2020) menunjukkan adanya proses penyesuaian harga lebih cepat dilakukan oleh provinsi yang berpasangan dalam satu pulau dibandingkan dengan provinsi yang berpasangan antar pulau.

Berdasarkan latar belakang diatas, kajian ini bertujuan mengkaji volatilitas harga dan transmisi harga daging sapi di Indonesia. Tidak seperti hasil penelitian lainnya yang mengkaji volatilitas harga Indonesia dengan menggunakan harga rata-rata nasional, kajian ini menganalisis dari harga harian daging sapi di empat provinsi yang menjadi sentra konsumen dan produsen yaitu Provinsi DKI Jakarta, Jawa Barat, Jawa Tengah, dan Jawa Timur.

DKI Jakarta merupakan provinsi yang mewakili daerah sentra konsumen atau daerah dengan konsumsi atau serapan daging sapi terbesar dan dapat menjadi acuan bagi pasar konsumen dan pelaku pasar lainnya. Nuryati \& Rostiani (2017) mengemukakan bahwa hampir $75 \%$ dari seluruh pasokan daging sapi lokal dan impor diserap oleh Propinsi DKI Jakarta, Bandung, dan Banten. Selain sebagai sentra konsumen, DKI Jakarta juga menjadi acuan bagi pasar konsumen dan pelaku pasar lainnya karena setiap kenaikan harga yang terjadi di DKI Jakarta, biasanya akan diikuti oleh kenaikan harga di beberapa daerah lainnya (Nuryati \& Rostiani, 2017). 
Sementara itu, tiga propinsi di Pulau Jawa yaitu Jawa Barat, Jawa Tengah, dan Jawa Timur merupakan daerah sentra produsen terbesar di Indonesia. Data dari PDSI Pertanian (2020) menunjukkan bahwa sentra produksi daging sapi terbesar berasal dari ketiga propinsi tersebut. Propinsi Jawa Timur merupakan sentra produksi daging sapi terbesar dengan kontribusi sekitar 20,00\% atau rata-rata 100,91 ribu ton, diikuti oleh Jawa Barat dengan kontribusi $15,45 \%$ atau rata-rata 77,97 ribu ton, dan ketiga adalah Propinsi Jawa Tengah dengan kontribusi terhadap total produksi daging sapi nasional sebesar $12,43 \%$ atau rata-rata 62,73 ribu ton.

Dengan menggunakan data harian daging sapi antara tahun 2017 dan 2020, analisis volatilitas harga dan transmisi harga dilakukan dengan menggunakan model ARCH/GARCH dan VAR/VECM. Berdasarkan hasil penelitian ini, diharapkan dapat diketahui informasi tentang provinsi dengan volatilitas harga terbesar dan pengaruh dari setiap perubahan harga yang terjadi di pasar dengan volatilitas harga terbesar terhadap pasar lainnya. Dengan diperolehnya informasi tersebut, diharapkan dapat menjadi rekomendasi kebijakan bagi pengambil kebijakan dalam mengatasi ketidakstabilan harga daging sapi.

\section{METODE}

Metode yang digunakan dalam penelitian ini terdiri dari dua yaitu analisis deskriptif dan analisis inferensia. Analisis deskriptif digunakan untuk mendeskripsikan data yang telah dianalisis dalam bentuk tabel atau gambar sehingga dapat mempermudah pembaca dalam memahami hasil penelitian (Sahara et al., 2019). Analisis deskriptif dalam penelitian ini digunakan untuk memberikan gambaran tentang pergerakan harga di keempat provinsi yang mewakili daerah sentra konsumen dan sentra produsen.

Analisis inferensia digunakan untuk mengkaji volatilitas harga dan transmisi harga di keempat provinsi tersebut. Tujuan pertama dilakukan untuk menganalisis provinsi mana yang memiliki volatilitas harga yang tinggi. Volatilitas harga penting untuk diketahui karena terkait dengan risiko yang harus dihadapi baik oleh petani produsen, pedagang perantara maupun konsumen. Informasi volatilitas harga juga penting untuk diketahui oleh pengambil kebijakan, agar dapat melakukan upaya antisipasi terhadap ketidakstabilan harga yang terjadi. 
Sementara itu, tujuan kedua dilakukan guna mengetahui efisiensi transmisi harga dari daerah dengan volatilitas harga tertinggi ke daerah lainnya. Efisiensi transmisi harga diperlukan guna mengetahui perilaku asimetri harga yang terjadi dalam pemasaran daging sapi antar lembaga pemasaran yang terlibat.

Data yang digunakan dalam penelitian ini adalah data sekunder berupa data harian harga daging sapi di Provinsi DKI Jakarta, Jawa Barat, Jawa Tengah dan Jawa Timur dari tanggal 1 Agustus 2017 hingga 31 Desember 2020. Data sekunder tersebut diperoleh dari Pusat Informasi Harga Pangan Strategis Nasional (PIHPS Nasional).

Metode pengolahan data dilakukan dalam dua tahap. Pertama, analisis volatilitas harga dilakukan dengan menggunakan model ARCH/GARCH. Model ARCH (p) dapat dirumuskan sebagai berikut:

$\sigma_{t}^{2}=\alpha_{0}+\alpha_{1} \varepsilon_{\mathrm{t}-1}^{2}+\alpha_{2} \varepsilon_{t-2}^{2}+\cdots+$ $\alpha_{p} \varepsilon_{t-p}^{2}$

$\sigma_{t}^{2}$ merupakan residu varian dan $\alpha_{p} \varepsilon_{t-p}^{2}$ dengan $\mathrm{p}=1,2, \ldots, \mathrm{n}$ merupakan komponen $\mathrm{ARCH}$, dengan $\varepsilon$ merupakan residual/error. Model $\mathrm{ARCH}$ diperoleh dari model persamaan rata-rata (conditional mean) atau model regresi univariat. Model ARCH (p) menunjukkan bahwa ragam dari residual $\varepsilon_{t}$ tergantung dari fluktuasi residual kuadrat $\mathrm{p}$ periode sebelumnya. Bollerslev kemudian melengkapi model $\mathrm{ARCH}$ yang diperkenalkan oleh Engle dengan menambahkan ragam residual periode yang lalu yang dikenal dengan model GARCH (Juanda \& Junaidi, 2012). Model GARCH (p,q) dapat dirumuskan sebagai berikut:

$$
\begin{aligned}
& \sigma_{t}^{2}=\alpha_{0}+\alpha_{1} \varepsilon_{\mathrm{t}-1}^{2}+\cdots+\alpha_{\mathrm{p}} \varepsilon_{\mathrm{t}-\mathrm{p}}^{2}+ \\
& \beta_{1} \sigma_{t-1}^{2}+\cdots+\beta_{\mathrm{q}} \sigma_{t-q}^{2} \ldots \ldots \ldots \ldots \ldots \ldots \ldots \ldots
\end{aligned}
$$

Model GARCH tersebut menunjukkan bahwa ragam residual $\left(\sigma_{t}^{2}\right)$ tidak hanya dipengaruhi oleh kuadrat residual $\mathrm{p}$ periode yang lalu $\left(\varepsilon_{\mathrm{t}-\mathrm{p}}^{2}\right)$, tetapi juga oleh ragam residual $\mathrm{q}$ periode sebelumnya $\left(\sigma_{t-q}^{2}\right)$. Kedua model ARCH dan $\mathrm{GARCH}$ diestimasi dengan menggunakan metode Maximum Likelihood (ML) (Juanda \& Junaidi, 2012).

Terdapat beberapa tahapan dalam menganalisis volatilitas harga, yaitu:

\section{Uji Unit Akar (Unit Root Test)}

Uji unit akar digunakan untuk mengidentifikasi apakah data sudah stasioner atau tidak. Hal ini penting untuk mencegah terjadinya spurious regression yang dapat menyebabkan hasil regresi yang belum tentu baik atau 
bias, baik tanda maupun besaran. Uji unit akar dilakukan dengan menggunakan Augmented Dickey Fuller Test (ADF test). Data yang tidak stasioner akan didiferensiasi hingga data tersebut menjadi stasioner dan tidak mengandung data yang bias.

\section{Identifikasi dan Penentuan Persamaan Rata-rata}

Persamaan rata-rata pada model $\mathrm{ARCH} / \mathrm{GARCH}$ dapat terdiri dari hanya intersep, harga periode sebelumnya (model ARIMA), variabel dummy, dan variabel penjelas lainnya. Kajian ini menggunakan model ARIMA (p,d,q). Model ARIMA terbaik ditentukan berdasarkan nilai Akaike Information Criterion (AIC) dan Schwartz Criterion (SC) terkecil, serta nilai log likelihood terbesar.

Model ARIMA tersebut juga harus memenuhi kriteria: memiliki residual yang acak, model parsimonious, parameter yang diestimasi secara signifikan berbeda dari nol, kondisi stasioneritas dipenuhi yang diindikasikan dari nomor koefisien AR dan MA yang masing-masing kurang dari satu, proses iterasi harus konvergen dan model tersebut harus memiliki nilai MSE yang kecil.

\section{Uji Heterokedastisitas}

Penentuan model ARCH/GARCH dapat dilakukan jika residual yang diperoleh dari persamaan rata-rata mengandung efek $\mathrm{ARCH}$ atau mengandung heterokedastisitas. Efek $\mathrm{ARCH}$ diuji dengan menggunakan uji Lagrange Multiplier (uji ARCH-LM) berdasarkan hipotesis null $\left(\mathrm{H}_{0}\right)$ tidak terdapat ARCH error. Jika hasil pengujian tidak menolak hipotesis null, berarti data tersebut tidak mengandung $\mathrm{ARCH}$ error dan tidak perlu menggunakan model ARCH-GARCH.

Setelah tahap satu hingga tiga dari analisis volatilitas harga daging sapi dilakukan, dapat diketahui bagaimana volatilitas harga daging sapi yang terjadi. Kriteria yang harus dimiliki model ARCH/GARCH adalah model harus memiliki koefisien yang signifikan, jumlah dari koefisien yang tidak boleh lebih dari $1(\alpha+\beta<1)$, dan koefisien tersebut tidak boleh memiliki nilai negatif $\left(\alpha_{0}>0, \alpha>0, \beta>0\right)$. Tinggi rendahnya volatilitas harga dapat dilihat dari nilai $\alpha$ atau efek $\mathrm{ARCH}$. Nilai $\alpha+\beta$ mendekati satu menunjukkan kecenderungan persistensi dari volatilitas dalam jangka panjang. $\alpha+\beta>1$ mengindikasikan data deret waktu yang melonjak lebih tinggi dari nilai rata-ratanya. 
Tahap kedua dari pengolahan data adalah menganalisis transmisi harga daging sapi antara sentra produsen dan konsumen. Analisis transmisi harga dilakukan dengan menggunakan model VAR/VECM. Sebelum dilakukan analisis transmisi harga, data yang digunakan diuji dulu stasioneritasnya dengan menggunakan ADF test seperti yang dilakukan pada analisis volatilitas harga dengan menggunakan model ARCH/GARCH di atas. Jika data harga stasioner pada level, maka digunakan model VAR dengan rumus umum sebagai berikut:

$\mathrm{X}_{\mathrm{t}}=\mathrm{A}_{0}+\sum_{\mathrm{i}=1}^{\mathrm{k}} \mathrm{A}_{\mathrm{i}} \mathrm{X}_{\mathrm{t}-1}+\mu_{\mathrm{t}}$

Dimana:

$X_{t}=$ vektor dari variabel terikat $(n \times 1)$ pada periode $t$

$\mathrm{X}_{\mathrm{t}-1}=$ vektor dari variabel terikat $(\mathrm{n} \times 1)$ periode $\mathrm{t}-1$

$A_{0}=$ vektor dari variabel eksogen termasuk di dalamnya konstanta atau intersep dan trend $(\mathrm{n} \times 1)$

$\mathrm{k}=$ jumlah lag atau ordo untuk model VAR

$\mu_{\mathrm{t}} \quad=$ vektor dari error $(\mathrm{n} \times 1)$

$A_{i}=$ matriks dari parameter, ukuran nxn untuk setiap $i=1,2, \ldots$.

Jika data yang diuji tidak stasioner pada level, dilakukan lagi uji selanjutnya hingga data tersebut sudah stasioner. yang terdiri dari: (1) menentukan panjang lag yang optimal untuk setiap variabel dengan data non-differenced. Model VAR tersebut diestimasi dengan menggunakan lag terbesar, kemudian secara bertahap diturunkan hingga mencapai lag satu hingga nol. Setiap model tersebut akan dinilai kelayakannya dengan menggunakan AIC dan SIC; (2) menguji hubungan jangka panjang dari setiap variabel dengan menggunakan uji kointerasi Johansen (the Johansen Cointegration Test) melalui dua tahap: (a) setiap variabel diuji dengan order integrasi yang sama, kalau terintegrasi pada order yang sama berarti data terkointegrasi; $\quad$ (b) Johansen cointegration test diaplikasikan pada series yang memiliki order integrasi yang sama. Jika data deret waktu terkointegrasi pada derajat satu, trace test (pendekatan Johansen) akan menunjukkan bahwa data memiliki hubungan jangka panjang.

Jika data ternyata stasioner pada first difference dan terkointegrasi pada jangka panjang, model yang digunakan adalah model Vector Error Correction Model (VECM). Penggunaan model VECM tersebut untuk menghindari adanya spurious regression atau pengambilan keputusan yang salah 
akibat regresi semu. Model VECM dirumuskan sebagai berikut:

$\Delta \mathrm{y}_{\mathrm{t}}=\mu_{0 x}+\mu_{1 x} t+$

$\prod_{x} y_{t-1}+\sum_{\mathrm{i}=1}^{\mathrm{k}-1} \tau_{\mathrm{i}} \Delta \mathrm{y}_{\mathrm{t}-\mathrm{i}}+\varepsilon_{\mathrm{t}}$

Dimana:

$\Delta y_{t} \quad=$ vektor yang berisi variabel yang dianalisis dalam penelitian (harga daging sapi di sentra produsen) periode $t$

$\Delta y_{t-i}=$ vektor yang berisi variabel yang dianalisis dalam penelitian (harga daging sapi di sentra produsen) periode $\mathrm{t}-\mathrm{i}$

$\mu_{0 x}=$ vektor intercept

$\mu_{1 x} \quad=$ vektor koefisien regresi

$t=$ trend waktu

$\Pi_{\mathrm{x}}=\mathrm{y} \times \beta$, dimana $\beta$ merupakan koefisien jangka panjang, dan Y merupakan kecepatan penyesuaian

$\tau=$ koefisien jangka pendek

$\Pi_{\mathrm{x}} \mathrm{y}_{\mathrm{t}-1}=$ Error Correction Term $(\mathrm{ECT})$

$\mathrm{k}-1 \quad=$ ordo VECM dari VAR

$\varepsilon_{\mathrm{t}} \quad=$ error term

Nilai ECT yang positif menunjukkan penyesuaian variabel dependen terhadap perubahan variabel independen saat penyimpangan harga berada di atas keseimbangannya. Sebaliknya, nilai ECT yang negatif menggambarkan penyesuaian variabel dependen terhadap perubahan variabel independen saat penyimpangan harga berada di atas keseimbangannya.

\section{HASIL DAN PEMBAHASAN}

\section{Volatilitas Harga Daging Sapi}

Harga merupakan salah satu indikator yang dapat digunakan untuk mengukur efisiensi perdagangan (Pagala et al., 2017). Harga terbentuk dari keseimbangan antara permintaan dan penawaran (ketersediaan). Dengan demikian, ketika permintaan lebih tinggi dari penawaran, hal tersebut mendorong terjadinya kenaikan harga daging sapi.

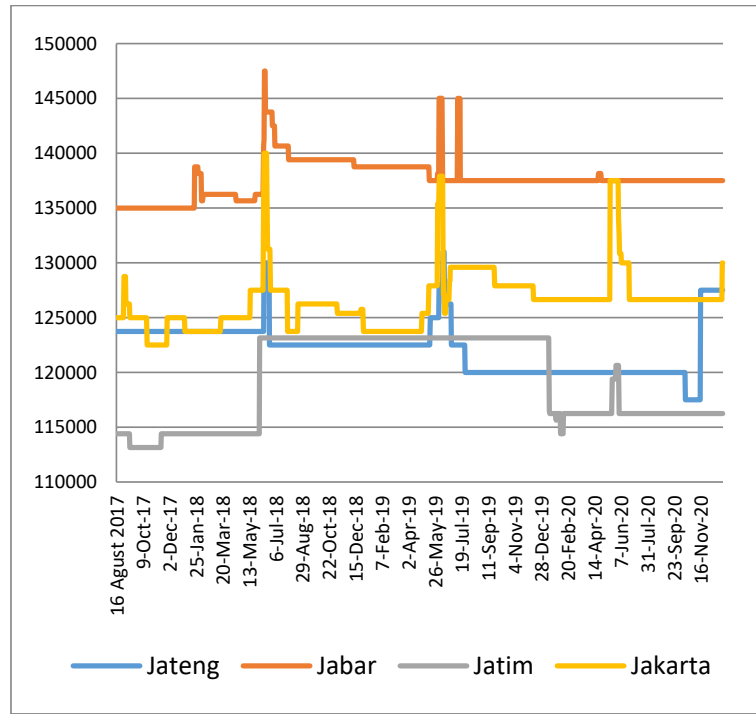

Gambar 1. Pergerakan Harga Harian Daging Sapi, Agustus 2017 - Desember 2020

Sumber: PDSI Pertanian (2020)

Gambar 1 menunjukkan bahwa harga harian daging sapi dari bulan Agustus 2017 hingga Desember 2020 mengalami fluktuasi dengan pola 
pergerakan yang berbeda di sentra konsumen DKI Jakarta dan di sentra produsen Jawa Barat, Jawa Tengah, dan Jawa Timur. Pergerakan harga daging sapi di DKI Jakarta dan Jawa barat terlihat lebih berfluktuasi dibandingkan dengan di Jawa Tengah dan Jawa Timur.

Guna mengetahui seberapa besar volatilitas harga daging sapi di keempat provinsi tersebut, dilakukan penghitungan dengan menggunakan model ARCH/GARCH. Selain mengetahui besaran fluktuasi harga di lokasi tersebut, model $\mathrm{ARCH} / \mathrm{GARCH}$ juga dapat digunakan untuk mengetahui persistensi dari fluktuasi yang terjadi tersebut.

Seperti yang telah dikemukakan pada metode penelitian di atas, tahap pertama dari uji volatilitas harga adalah melakukan uji stasioneritas. Uji stasioneritas dilakukan guna melihat konsistensi pergerakan data time series, serta mencegah terjadinya spurious regression (Sahara et al., 2019). Spurious regression merupakan keadaan dimana hasil pengolahan data regresi menghasilkan nilai $R^{2}$ yang tinggi, namun pada kenyataanya tidak terdapat hubungan ekonomi yang berarti antara variabel dalam persamaan regresi tersebut.
Uji stasioneritas dilakukan beberapa kali hingga data tersebut telah stasioner. Jika data tersebut telah stasioner tanpa dilakukan differencing, maka data dapat dikatakan telah stasioner pada level atau I(0). Jika data tersebut stasioner setelah dilakukan differencing pada turunan pertama, maka data tersebut telah stasioner pada first difference atau terintegrasi pada order pertama I(1). Jika data tersebut stasioner setelah dilakukan differencing pada turunan ke-d, maka data series tersebut telah terintegrasi pada order ke-d atau I(d).

Uji stasioneritas dilakukan dengan menggunakan Augmented Dickey Fuller (ADF) test. Hasil uji ADF disajikan pada Tabel 1. Tabel 1 menunjukkan bahwa data logarithma harga riil harian daging sapi di DKI Jakarta, dan Jawa Barat telah memiliki nilai t-statistik yang lebih besar dari nilai kritis atau probabilitas yang lebih besar dari taraf nyata (alpha) 1\%. Dengan kata lain, data harga daging sapi di DKI Jakarta dan Jawa Barat telah stasioner pada level atau I(0). Sementara itu, data harga daging sapi di Jawa Tengah dan Jawa Timur tidak stasioner pada level. Hal tersebut ditunjukkan oleh nilai t-statistik yang lebih besar dari nilai kritis, sehingga perlu untuk diturunkan terlebih dahulu 
agar diperoleh data harga yang stasioner.

Tabel 1. Hasil Uji Stasioneritas Harga Riil Harian Daging Sapi

\begin{tabular}{lccc}
\hline & Level & First diff. & $\begin{array}{c}\text { Nilai Kritis } \\
1 \%\end{array}$ \\
\hline Uji ADF & & & \\
Jakarta & $-4,90$ & $-29,68$ & $-3,43$ \\
& 0,00 & 0,00 & \\
Bandung & $-4,82$ & $-16,20$ & $-3,43$ \\
& 0,00 & 0,00 & \\
Smarang & $-2,13$ & $-35,08$ & $-3,43$ \\
& 0,23 & 0,00 & \\
Surabaya & $-1,73$ & $-34,79$ & $-3,43$ \\
& 0,41 & 0,00 & \\
\hline
\end{tabular}

Hasil uji ADF pada turunan pertama atau lag pertama dari log harga riil harian daging sapi di Semarang, dan Surabaya menunjukkan nilai t-statistik yang lebih besar dari nilai kritis dan nilai probabilitas yang lebih kecil dari $1 \%$ (Tabel 1). Dengan demikian, dapat disimpulkan bahwa data harga riil harian daging sapi di Semarang dan Surabaya stasioner pada first difference atau lag pertama.

Tahap selanjutnya menentukan persamaan rata-rata yang diambil dari model ARIMA terbaik berdasarkan nilai log likelihood terbesar, dan nilai Akaike Info Criterion (AIC) dan Schwarz Criterion (SC) terkecil. Setelah menentukan model persamaan ratarata terbaik, dilakukan uji heterokedastisitas untuk menentukan keberadaan efek $\mathrm{ARCH}$.

Tabel 2 menunjukkan bahwa persamaan rata-rata untuk data harga daging sapi di keempat propinsi menunjukkan hasil yang berbeda-beda. Persamaan rata-rata untuk harga DKI Jakarta adalah MA(1). Sementara itu, persamaan rata-rata di harga daging sapi di Bandung dan Semarang adalah ARIMA (1,1), dan Surabaya adalah $\operatorname{ARIMA}(2,2)$.

Tabel 2. Penentuan Persamaan Ratarata dan Hasil Uji Heterokedastisitas Harga Riil Daging Sapi

\begin{tabular}{cccc}
\hline \multirow{5}{*}{ Jakarta } & $\begin{array}{c}\text { Persamaan } \\
\text { Rata-rata }\end{array}$ & F-stats & $\begin{array}{c}\text { Obs }^{*} \mathrm{R}- \\
\text { squared }\end{array}$ \\
\hline \multirow{5}{*}{ Bandung } & MA(1) & 231,76 & 195,36 \\
& ARIMA & 89,91 & 83,92 \\
& $(1,1)$ & $(0.00$ & $(0,00)$ \\
Semarang & ARIMA & 0,01 & 0,01 \\
& $(1,1)$ & $(0,91)$ & $(0,90)$ \\
& ARIMA & 0.01 & 0,01 \\
& $(2,2)$ & $(0,94)$ & $(0,94)$ \\
\hline
\end{tabular}

Ket: nilai dalam kurung pada persamaan ratarata menunjukkan ordo dari persamaan ARIMA; nilai kurung pada F-stats dan Obs* ${ }^{*}$-squared adalah nilai probabilitas

Hasil uji heterokedastisitas dengan menggunakan uji ARCH-LM pada Tabel 2 menunjukkan bahwa untuk harga riil harian daging sapi di keempat provinsi, hanya dua propinsi yang memiliki nilai 
Obs ${ }^{*} R$-squared dan nilai F-statistik dengan nilai probabilitas sangat signifikan ( $p<0,01$; Tabel 2$)$, yaitu Jakarta dan Bandung. Dengan demikian, terdapat efek $\mathrm{ARCH}$ pada data harga rill harian Jakarta dan Bandung, sehingga dapat diestimasi lebih lanjut dengan menggunakan model ARCH/GARCH.

Sementara itu, harga riil harian daging sapi di Semarang dan Surabaya memiliki nilai $O b s^{*} R$-squared dan nilai F-statistik dengan nilai probabilitas yang tidak signifikan ( $p>0,01$; Tabel 2). Dapat disimpulkan bahwa tidak terdapat efek $\mathrm{ARCH}$ pada data harga riil harian daging sapi di Semarang dan Surabaya. Harga riil harian daging sapi di Semarang dan Surabaya hanya dipengaruhi oleh perubahan harga riil dan fluktuasi harga daging sapi dari satu dan dua periode sebelumnya. Tidak adanya efek $\mathrm{ARCH}$ pada persamaan ARIMA menunjukkan bahwa perubahan harga riil di pasar daging sapi Semarang dan Surabaya relatif tidak berfluktuasi atau stabil.

Berdasarkan hasil uji heterokedastisitas, dilakukan estimasi model volatilitas harga riil harian daging sapi di Jakarta dan Jawa Barat. Hasil estimasi menunjukkan bahwa model volatilitas harga terbaik untuk Jakarta adalah $\operatorname{GARCH}(1,1)$, dan Jawa Barat yang diwakili oleh Bandung adalah GARCH $(1,0)$. Selain memiliki nilai log likelihood terbesar, AIC dan SIC terkecil, model ini juga memiliki hasil uji ARCHLM yang tidak signifikan pada taraf nyata $1 \%$ (Tabel 3 ). Dengan kata lain, model terbebas dari efek $\mathrm{ARCH}$ dan telah terspesifikasi dengan baik.

Tabel 3. Hasil

Estimasi

Model

Volatilitas Harga Daging Sapi

\begin{tabular}{lcc}
\hline \multicolumn{1}{c}{ Koefisien } & Jkt & Bdg \\
\hline Pers. Rata-rata & & \\
Konstanta & $11,48^{\star * *}$ & $11,57^{* * *}$ \\
AR(1) & - & $0,97^{* * *}$ \\
MA(1) & $0,83^{\star * *}$ & $-0,31^{* * *}$ \\
Pers. Ragam & & \\
$\omega$ (konstanta) & $0,00^{* * *}$ & $0,00^{* * *}$ \\
$\alpha($ ARCH) & $0,56^{* * *}$ & $0,17^{* *}$ \\
$\beta$ (GARCH) & $0,43^{* * *}$ & - \\
$\alpha+\beta$ & 0,99 & 0,17 \\
Uji ARCH-LM & & \\
Uji statistik & 0,86 & 0,06 \\
Prob. Chi-Square & 0,86 & 0,06 \\
\hline
\end{tabular}

Ket: $\left({ }^{* * *}\right)$ signifikan pada taraf nyata $1 \%$

Model volatilitas harga untuk Jakarta menunjukkan bahwa volatilitas harga rill daging sapi di Jakarta dipengaruhi oleh volatilitas harga dan ragam volatilitas harga periode sebelumnya. Dengan kata lain, ketika terjadi fluktuasi harga pada suatu periode, para pelaku pasar sudah harus mengantisipasi terjadinya volatilitas harga riil daging sapi di periode selanjutnya. Sementara itu, volatilitas 
harga di Jawa Barat atau Bandung hanya dipengaruhi oleh volatilitas harga periode sebelumnya. Dengan demikian, ketika terjadi volatilitas harga pada suatu periode, akan diikuti oleh ketidakpastian harga pada periode berikutnya.

Hasil estimasi GARCH $(1,1)$ untuk data harga riil harian daging sapi Jakarta menunjukkan nilai a sebesar 0,56 atau volatilitas harga riil harian daging sapi yang rendah. Sementara itu, hasil estimasi GARCH $(1,0)$ untuk data harga riil harian daging sapi Bandung menunjukkan nilai a sebesar 0,17 atau volatilitas harga yang lebih rendah dari Jakarta.

Jumlah nilai $\alpha$ dan $\beta$ untuk harga riil harian daging sapi di DKI Jakarta sebesar 0,99. Nilai $\alpha$ dan $\beta$ yang mendekati 1 menunjukkan bahwa volatilitas harga daging sapi di Jakarta memiliki persistensi yang tinggi dalam jangka panjang. Dengan kata lain, ketika volatilitas atau ketidakpastian perubahan harga daging sapi terjadi, volatilitas harga tersebut akan terus terjadi dalam jangka panjang. Sementara itu, nilai $\beta$ yang tidak terdapat pada harga riil harian daging sapi di Bandung menunjukkan bahwa volatilitas harga yang terjadi tidak akan berlangsung lama.
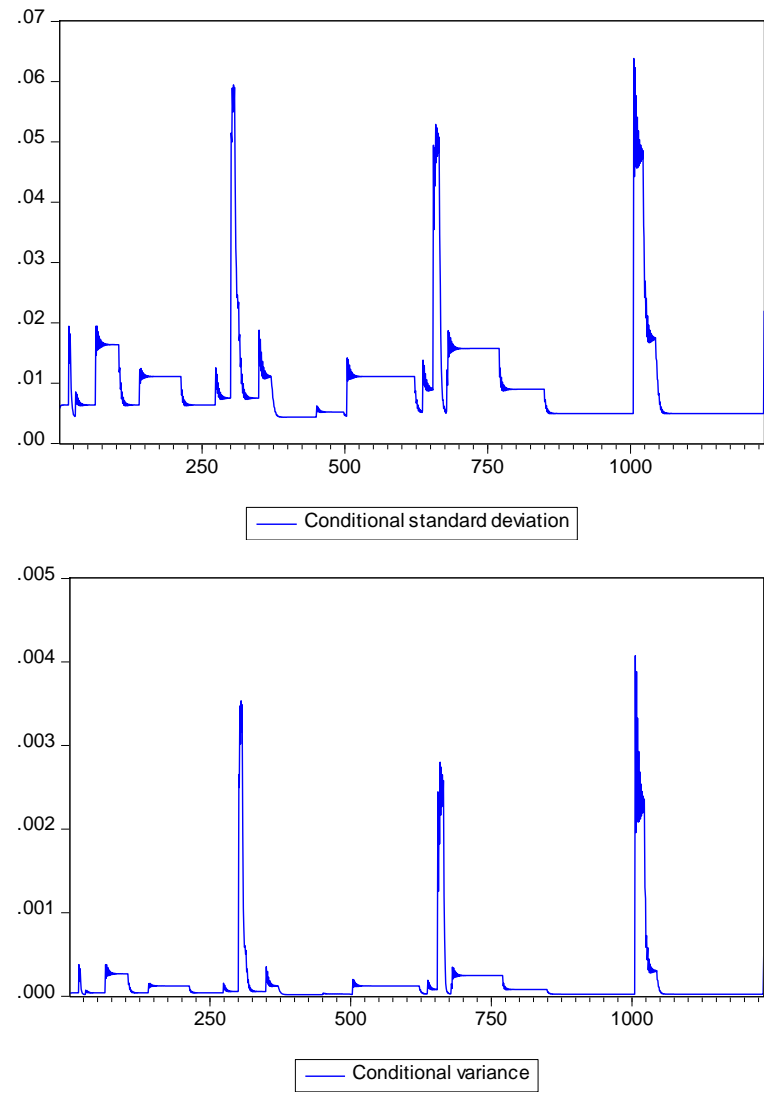

Gambar 2. Volatilitas Harga Harian Daging Sapi di DKI Jakarta Bulan Agustus 2017 Desember 2020

Berdasarkan hasil penelitian ini, dapat disimpulkan bahwa volatilitas harga hanya terjadi di DKI Jakarta sebagai sentra konsumen dan jika terjadi akan terus berlangsung dalam jangka panjang. Untuk itu, pemerintah sebaiknya melakukan pengawasan atau monitoring terhadap perubahan harga yang terjadi di pasar DKI Jakarta, agar dapat segera dilakukan upaya antisipasi sebelum terjadinya volatilitas harga.

Berdasarkan Gambar 2, volatilitas harga di DKI Jakarta terdiri dari volatilitas harga yang bersifat musiman 
dan volatilitas harga yang terjadi sewaktu-waktu. Volatilitas harga atau perubahan harga yang tidak menentu yang bersifat musiman ditunjukkan oleh adanya pergerakan kurva yang paling tinggi. Pergerakan harga yang tidak menentu tersebut biasanya terjadi selama periode bulan Ramadhan, hari raya Idul Fitri hingga beberapa minggu setelah bulan Ramadhan. Sementara itu, volatilitas yang tidak dapat diprediksi seperti pergerakan volatilitas harga yang relatif rendah di sekitar volatilitas harga yang tinggi disebabkan oleh adanya kebijakan impor daging sapi dan lainnya. Hasil kajian Komalawati et al. (2018) menunjukkan bahwa salah satu faktor yang memengaruhi terjadinya fluktuasi harga yang tidak menentu adalah adanya impor sapi bakalan dan kebijakan yang memengaruhinya.

Volatilitas harga juga dapat dipengaruhi oleh perilaku spekulasi dari para pelaku pasar terutama pedagang perantara. Menurut Sahara et al. (2019), dalam perdagangan suatu komoditas terdapat tiga pelaku pasar yang berperan yaitu produsen, konsumen, dan pedagang perantara selaku pihak yang menyampaikan barang dari produsen kepada konsumen. Hasil kajian Sahara et al. (2019) menunjukkan bahwa fluktuasi harga pada komoditi bawang merah cenderung lebih menguntungkan pedagang perantara. $\mathrm{Hal}$ ini disebabkan oleh perilaku pedagang perantara yang seringkali memanipulasi informasi harga di tingkat petani dengan merespon cepat setiap kenaikan harga yang terjadi di produsen, tetapi cenderung merespon lambat atau tidak mengubah harga di tingkat konsumen ketika terjadinya penurunan harga (Simatupang, 1999). Terjadinya informasi harga yang tidak sama antara pedagang, konsumen dan produsen menunjukkan dugaan adanya asimetri harga yang ditransmisikan dari sentra produsen ke sentra konsumen. Hal inilah yang akan dibahas pada bagian berikutnya.

\section{Transmisi Harga Daging Sapi}

Analisis transmisi harga daging sapi yang menjadi tujuan kedua dari penelitian ditujukan untuk mengetahui apakah perubahan harga yang terjadi di Pasar DKI Jakarta atau sentra konsumen akan berpengaruh terhadap pasar lainnya di sentra produsen Jawa Barat, Jawa Tengah, dan Jawa Timur. Adanya dugaan asimetri harga pada transmisi harga dari sentra konsumen kepada sentra produsen diharapkan juga dapat menjawab penyebab terjadinya volatilitas harga daging sapi di pasar DKI Jakarta dan Bandung yang 
diperkirakan sebagai dua sentra konsumen daging sapi terbesar di Indonesia.

Langkah pertama untuk melakukan analisis transmisi harga adalah dengan melakukan uji stasioneritas pada data harga daging sapi di keempat propinsi. Uji stasioneritas ini telah dilakukan sebelum melakukan analisis ARCH/GARCH. Hasil uji stasioneritas pada Tabel 1 menunjukkan bahwa harga riil harian daging sapi DKI Jakarta dan Jawa Barat stasioner pada level, sedangkan harga riil harian daging sapi Jawa Tengah dan Jawa Timur stasioner pada first difference. Agar dapat dilakukan uji kointegrasi, maka seluruh variabel data harus disesuaikan stasioneritasnya di first difference. Menurut Sahara et al (2019), variabel yang tidak stasioner di level mengindikasikan adanya hubungan jangka panjang dan perlu untuk dilakukan uji kointegrasi untuk memastikannya. Sebelum melakukan uji kointegrasi, dilakukan terlebih dahulu penentuan lag optimum.

Penentuan lag optimum ditujukan untuk melihat waktu yang diperlukan oleh suatu variabel untuk bereaksi terhadap perubahan variabel lainnya. Penentuan lag optimum juga digunakan untuk menghilangkan masalah autokorelasi dan heterokedastisitas dalam sistem VAR/VECM.

Berdasarkan nilai SIC dan Hannan-Quinn information criterion $(H Q)$, harga riil harian daging sapi di Jakarta, Bandung, Semarang dan Surabaya dapat bereaksi terhadap variabel lainnya antara dua hingga 5 hari (-2 dan -5). Dengan demikian, lag optimum yang akan digunakan dalam model VAR/VECM adalah lag 2. Hal ini berdasarkan pada penentuan lag optimal dengan menggunakan SIC.

\section{Tabel 4. Hasil Uji Lag Optimum}

\begin{tabular}{cccc}
\hline \multirow{2}{*}{ Lag } & \multirow{2}{*}{ Log $\mathrm{R}$} & \multicolumn{2}{c}{ Kriteria } \\
\cline { 3 - 4 } & & SIC & $\mathrm{HQ}$ \\
\hline 0 & -44411.21 & 72.47 & 72.46 \\
1 & -36088.45 & 58.99 & 58.94 \\
2 & -35990.71 & $58.92^{*}$ & 58.83 \\
3 & -35970.30 & 58.98 & 58.84 \\
4 & -35913.17 & 58.98 & 58.80 \\
5 & -35871.61 & 59.00 & $58.79^{*}$ \\
\hline
\end{tabular}

Ket: *indikasi lag order berdasarkan kriteria

Tahap selanjutnya setelah penentuan lag optimum adalah melakukan uji kointegrasi. Uji kointegrasi digunakan untuk mengetahui hubungan jangka panjang antar semua variabel harga yang digunakan. Penelitian ini menggunakan uji kointegrasi dengan pendekatan Johansen cointegration test dengan lag 1 hingga 2 dengan asumsi yang dipilih adalah linear and quadratic 
deterministic trend. Hasil uji kointegrasi pada variabel harga riil harian daging sapi di DKI Jakarta, Jawa Barat, Jawa Tengah, dan Jawa Timur disajikan pada Tabel 5.

\section{Tabel 5. Hasil Uji Kointegrasi}

\begin{tabular}{|c|c|c|c|c|}
\hline $\begin{array}{c}\text { Variabel } \\
\text { Harga }\end{array}$ & I & $\begin{array}{c}\text { Trace } \\
\text { Statistis }\end{array}$ & $\begin{array}{l}\text { Max- } \\
\text { eigen } \\
\text { Value }\end{array}$ & $\begin{array}{c}\text { Critical } \\
\text { Value } \\
(5 \%)\end{array}$ \\
\hline \multirow{2}{*}{$\begin{array}{l}\text { Jakarta -> } \\
\text { Jabar }\end{array}$} & None* $^{*}$ & 57.008 & 0.030 & 18.398 \\
\hline & At most $1^{*}$ & 20.030 & 0.016 & 3.841 \\
\hline \multirow{2}{*}{$\begin{array}{l}\text { Jakarta -> } \\
\text { Jateng }\end{array}$} & None* & 45.189 & 0.026 & 18.398 \\
\hline & At most $1^{*}$ & 13.226 & 0.011 & 3.841 \\
\hline \multirow{2}{*}{$\begin{array}{l}\text { Jakarta -> } \\
\text { Jatim }\end{array}$} & None* & 28.936 & 0.021 & 15.495 \\
\hline & At most 1 & 3.142 & 0.002 & 3.841 \\
\hline
\end{tabular}

Keterangan: *Tolak $\mathrm{H}_{0}$

Pada Tabel 5 menunjukkan adanya hubungan kointegrasi (integrasi jangka panjang) antara pasar daging sapi DKI Jakarta dan pasar daging sapi di Jawa Barat, Jawa Tengah, dan Jawa Timur. Hal ini ditunjukkan oleh nilai trace statistic dan maximum eigenvalue yang menolak $\mathrm{H}_{0}$ sampai pada tingkat signifikansi $5 \%$ pada rank 1 . Hal ini menunjukkan bahwa paling tidak terdapat satu persamaan kointegrasi (integrasi jangka panjang). Dengan demikian, terdapat satu persamaan yang dapat menjelaskan adanya hubungan kointegrasi pada variabelvariabel dalam model. Berdasarkan hasil uji kointegrasi, dapat dilakukan estimasi transmisi harga daging sapi antara DKI Jakarta dan Jawa Barat, DKI
Jakarta dan Jawa Tengah, serta DKI Jakarta dan Jawa Timur dengan menggunakan model Vector Error Correction Model (VECM).

\section{Hasil Estimasi VECM Pasar DKI Jakarta dan Jawa Barat}

Hasil estimasi model VECM terdiri dari hasil estimasi kointegrasi jangka panjang dan jangka pendek. Hasil estimasi untuk kointegrasi jangka panjang disajikan pada Tabel 6.

Tabel 6. Kointegrasi Jangka Panjang antar Pasar Daging Sapi Jakarta dan Jawa Barat

\begin{tabular}{cccc}
\hline Persamaan & \multicolumn{3}{c}{ Variabel Harga } \\
\cline { 2 - 4 } Kointegrasi & PJKT & PBDG & C \\
\hline Kointegrasi 1 & 1.000 & $0.798^{* *}$ & -20.70 \\
& & $(0.324)$ & \\
& \multicolumn{3}{c}{$[2.464]$} \\
\hline
\end{tabular}

Ket: Angka dalam [ ] adalah nilai t-statistik; ${ }^{* *}=$ nyata pada taraf $1 \% ;{ }^{* *}=$ nyata pada taraf $5 \%$; dan ${ }^{*}=$ nyata pada taraf $10 \%$. Nilai $t$ tabel: $\mathrm{t}(\alpha=1 \%)=2.576, \mathrm{t}(\alpha=5 \%)=1.960$, $\mathrm{t}(\mathrm{\alpha}=10 \%)=1.645$

Berdasarkan Tabel 6, dapat diketahui bahwa hanya terdapat satu persamaan yang mengalami kointegrasi pada integrasi pasar daging sapi Jawa Barat dan DKI Jakarta. Hasil estimasi VECM mengindikasikan bahwa pergerakan harga daging sapi di DKI Jakarta dalam jangka panjang dipengaruhi secara signifikan ( $p>0,05$; Tabel 6) oleh pergerakan harga daging sapi di Jawa Barat. 
Harga daging sapi Jawa Barat berpengaruh positif terhadap harga daging sapi DKI Jakarta sebesar 0.798. Tanda positif menunjukkan bahwa perubahan harga di tingkat produsen akan memengaruhi perubahan harga di tingkat konsumen secara searah. Nilai 0.798 menunjukkan bahwa setiap peningkatan harga di pasar Jawa Barat sebesar 1\% akan direspon dengan peningkatan harga di tingkat konsumen sebesar $0.798 \%$. Pengaruh perubahan harga di Jawa Barat terhadap harga di DKI Jakarta menunjukkan perubahan inelastis dalam jangka panjang. Dengan kata lain, harga daging sapi di Jawa Barat tidak terlalu besar memengaruhi harga daging sapi di DKI Jakarta. Rendahnya pengaruh perubahan harga daging sapi di Jawa Barat sebagai salah satu sentra produsen terhadap harga di Jakarta disebabkan oleh pasokan daging sapi di Jakarta yang tidak hanya dari produsen daging sapi lokal tetapi juga dari impor. Hal ini juga sejalan dengan hasil penelitian Kusriatmi et al. (2014) dan Komalawati et al. (2019) yang menunjukkan besarnya pengaruh impor daging sapi terhadap ketersediaan daging sapi di Indonesia.

Tabel 7 menunjukkan hasil analisis output VECM yang berupa nilai koreksi kesalahan ECM. Nilai ECM menunjukkan kecepatan penyesuaian dari keseimbangan jangka pendek menuju keseimbangan jangka panjang. Berdasarkan Tabel 8, diketahui bahwa nilai ECM harga daging sapi di pasar DKI Jakarta dan Jawa Barat signifikan ( $p>0,01$ dan $p>0.10$ ). Dengan demikian, kedua harga baik di pasar DKI Jakarta maupun pasar Jawa Barat dapat menyesuaikan menuju keseimbangan jangka panjang.

Tabel 7. Kointegrasi Jangka Pendek antar Pasar Daging Sapi Jakarta dan Jawa Barat

\begin{tabular}{|c|c|c|}
\hline $\begin{array}{c}\text { Error } \\
\text { Correction }\end{array}$ & $\mathrm{D}$ (PJKT) & $\mathrm{D}$ (PBDG) \\
\hline CointEq1 & $\begin{array}{c}-0.035^{\star \star *} \\
(0.006) \\
{[-6.047]}\end{array}$ & $\begin{array}{c}-0.009^{*} \\
(0.005) \\
{[-1.811]}\end{array}$ \\
\hline $\mathrm{D}(\mathrm{PJKT}(-1))$ & $\begin{array}{c}0.143^{\star * \star} \\
(0.028) \\
{[5.022]}\end{array}$ & $\begin{array}{c}0.073^{\star * \star} \\
(0.024) \\
{[3.017]}\end{array}$ \\
\hline $\mathrm{D}(\mathrm{PJKT}(-2))$ & $\begin{array}{c}0.004 \\
(0.028) \\
{[0.143]}\end{array}$ & $\begin{array}{c}0.117^{\star * \star} \\
(0.024) \\
{[4.846]}\end{array}$ \\
\hline $\mathrm{D}(\operatorname{PBDG}(-1))$ & $\begin{array}{c}0.224^{\star * *} \\
(0.034) \\
{[6.599]}\end{array}$ & $\begin{array}{c}-0.278^{* * *} \\
(0.288) \\
{[-9.677]}\end{array}$ \\
\hline $\mathrm{D}(\mathrm{PBDG}(-2))$ & $\begin{array}{c}0.110^{* \star *} \\
(0.034) \\
{[3.203]}\end{array}$ & $\begin{array}{c}-0.081^{* * *} \\
(0.029) \\
{[-2.806]}\end{array}$ \\
\hline C & $\begin{array}{c}-2.73 E-05 \\
(0.000) \\
{[-0.100]}\end{array}$ & $\begin{array}{c}8.43 \mathrm{E}-05 \\
(0.000) \\
{[0.368]}\end{array}$ \\
\hline
\end{tabular}

Ket: Angka dalam [ ] adalah nilai t-statistik; ${ }^{* * *}=$ nyata pada taraf $1 \%$; ${ }^{* *}=$ nyata pada taraf $5 \%$; dan ${ }^{*}=$ nyata pada taraf $10 \%$. Nilai $t$ tabel: $\mathrm{t}(\alpha=1 \%)=2.576, \mathrm{t}(\alpha=5 \%)=1.960$, $\mathrm{t}(\alpha=10 \%)=1.645$

Nilai ECM pada harga pasar DKI Jakarta sebesar -0,035 menunjukkan bahwa terdapat penyesuaian dari jangka pendek menuju jangka panjang 
sebesar -0,035 atau setiap bulan kesalahan dikoreksi sebesar -0,035 menuju keseimbangan jangka panjang. Sementara itu, nilai ECM pada harga pasar Jawa Barat sebesar -0,009. Nilai tersebut menunjukkan bahwa terdapat penyesuaian dari jangka pendek menuju jangka panjang sebesar -0,009 atau kesalahan akan dikoreksi setiap bulan sebesar -0,009 menuju keseimbangan jangka panjang.

Selain nilai ECM, Tabel 7 juga menunjukkan hasil kointegrasi jangka pendek antara kedua pasar. Hasil kointegrasi menunjukkan bahwa harga daging sapi di pasar Jakarta dipengaruhi secara signifikan $(p>0,01)$ oleh harga itu sendiri satu periode sebelumnya dan harga di pasar Jawa Barat hingga dua periode sebelumnya. Sementara itu, harga Jawa Barat dipengaruhi secara signifikan $(p>0,01)$ oleh harga di pasar Jawa Barat dari dua periode sebelumnya dan harga di pasar DKI Jakarta dari dua periode sebelumnya. Pengaruh harga di pasar Jakarta terhadap pasar Jawa Barat yang sama sebesar dua periode menunjukkan bahwa transmisi harga antara pasar Jakarta dan Jawa Barat adalah simetri dalam hal waktu penyesuaian.
Namun demikian, dari sisi magnitude, terdapat perbedaan koefisien pengaruh dari perubahan harga di Jawa Barat terhadap perubahan harga di Jakarta dan sebaliknya. Harga daging sapi di Pasar Jawa Barat dua bulan sebelumnya memiliki nilai 0,110. Nilai tersebut menunjukkan bahwa jika terjadi peningkatan harga di pasar Jawa Barat dua periode sebelumnya sebesar $1 \%$ akan menyebabkan peningkatan harga di Pasar DKI Jakarta sebesar 0,110\%. Sementara itu, harga daging sapi di Pasar Jakarta dua bulan sebelumnya memiliki pengaruh sebesar 0,117 . Nilai tersebut menunjukkan bahwa setiap peningkatan harga daging sapi di Pasar Jakarta dua periode sebelumnya meningkat sebesar $1 \%$ akan meningkatkan harga daging sapi di Pasar Jawa Barat sebesar 0,117\%. Adanya perbedaan magnitude kecepatan penyesuaian pada kedua pasar dalam jangka pendek dan integrasi satu arah dalam jangka panjang dapat menjadi salah satu indikasi bahwa pasar daging sapi di DKI Jakarta dan Jawa Barat belum efisien.

\section{Hasil Estimasi VECM Pasar DKI Jakarta dan Jawa Tengah \\ Hasil estimasi model VECM terdiri dari hasil estimasi kointegrasi jangka}


panjang dan jangka pendek. Hasil estimasi untuk kointegrasi jangka panjang disajikan pada Tabel 8.

Tabel 8. Kointegrasi Jangka Panjang antar Pasar Daging Sapi Jakarta dan Jawa Tengah

\begin{tabular}{cccc}
\hline Persamaan & \multicolumn{3}{c}{ Variabel Harga } \\
\cline { 2 - 4 } Kointegrasi & PJKT & PSMG & C \\
\hline Kointegrasi 1 & 1.000 & 0.326 & -15.20 \\
& & $(0.231)$ \\
& \multicolumn{3}{c}{$[1.413]$} \\
\hline
\end{tabular}

Ket: Angka dalam [ ] adalah nilai t-statistik; ${ }^{* * *}=$ nyata pada taraf $1 \% ;{ }^{* *}=$ nyata pada taraf $5 \%$; dan ${ }^{*}=$ nyata pada taraf $10 \%$. Nilai $\mathrm{t}$ tabel: $\mathrm{t}(\alpha=1 \%)=2.576, \mathrm{t}(\alpha=5 \%)=1.960$, $\mathrm{t}(\mathrm{\alpha}=10 \%)=1.645$

Berdasarkan Tabel 8, dapat diketahui bahwa terdapat satu persamaan yang mengalami kointegrasi pada integrasi pasar daging sapi Jawa Tengah dan DKI Jakarta. Hasil estimasi VECM mengindikasikan bahwa pergerakan harga daging sapi di DKI Jakarta dalam jangka panjang dipengaruhi secara tidak signifikan oleh pergerakan harga daging sapi di Semarang. Hal ini ditunjukkan oleh nilai t-hitung harga daging sapi Semarang yang lebih kecil dari nilai t-statistik pada taraf kepercayaan $1 \%, 5 \%$ dan $10 \%$. Dengan demikian, tidak ada penyesuaian harga di Pasar Jawa Tengah menuju keseimbangan jangka panjang.
Tabel 9 menunjukkan hasil kointegrasi jangka pendek antara pasar Jakarta dan Semarang. Nilai ECM harga daging sapi di pasar Jakarta signifikan ( $p>0,01$; Tabel 9). Sementara itu, nilai ECM harga daging sapi di Semarang tidak signifikan. Dengan demikian, hanya harga daging sapi Jakarta yang dapat menyesuaikan menuju keseimbangan jangka panjang.

Nilai ECM pada harga pasar DKI Jakarta sebesar -0,039 menunjukkan bahwa terdapat penyesuaian dari jangka pendek menuju jangka panjang sebesar -0,039 atau setiap bulan kesalahan dikoreksi sebesar -0,039 menuju keseimbangan jangka panjang.

Tabel 9. Kointegrasi Jangka Pendek antar Pasar Daging Sapi Jakarta dan Jawa Tengah

\begin{tabular}{ccc}
\hline Error Correction & $\mathrm{D}(\mathrm{PJKT})$ & $\mathrm{D}(\mathrm{PSMG})$ \\
\hline CointEq1 & $-0.039^{\star * *}$ & -0.003 \\
& $(0.007)$ & $(0.006)$ \\
& {$[-5.660]$} & {$[-0.539]$} \\
\hline $\mathrm{D}(\mathrm{PJKT}(-1))$ & $0.182^{\star * *}$ & $0.093^{\star * *}$ \\
& $(0.028)$ & $(0.022)$ \\
& {$[6.450]$} & {$[4.136]$} \\
\hline $\mathrm{D}(\mathrm{PJKT}(-2))$ & 0.019 & 0.006 \\
& $(0.029)$ & $(0.023)$ \\
& {$[0.667]$} & {$[0.259]$} \\
\hline $\mathrm{D}(\mathrm{PSMG}(-1))$ & $-0.010^{\star * *}$ & $-0.006^{\star \star *}$ \\
& $(0.036)$ & $(0.029)$ \\
& {$[-0.275]$} & {$[-0.204]$} \\
\hline $\mathrm{D}(\mathrm{PSMG}(-2))$ & $0.113^{\star * *}$ & -0.006 \\
& $(0.036)$ & $(0.028)$ \\
& {$[3.144]$} & {$[-0.214]$} \\
\hline $\mathrm{C}$ & $-1.36 \mathrm{E}-05$ & -0.000 \\
& $(0.000)$ & $(0.000)$ \\
& {$[-0.050]$} & {$[-0.886]$} \\
\hline
\end{tabular}

Ket: Angka dalam [ ] adalah nilai t-statistik; ${ }^{* *}=$ nyata pada taraf $1 \% ;{ }^{* *}=$ nyata pada taraf $5 \%$; dan ${ }^{*}=$ nyata pada taraf $10 \%$. Nilai $\mathrm{t}$ tabel $: \mathrm{t}(\alpha=1 \%)=2.576, \mathrm{t}(\alpha=5 \%)=1.960$, $t(\alpha=10 \%)=1.645$ 
Hasil estimasi model VECM pada Tabel 9 menunjukkan bahwa transmisi harga daging sapi di pasar pengecer Jawa Tengah dan DKI Jakarta dipengaruhi oleh harga daging sapi di pasar itu sendiri dari satu periode sebelumnya. Harga daging sapi di Pasar Jakarta dipengaruhi oleh harga daging sapi di pasar Jawa Tengah dari dua periode sebelumnya. Sementara itu, harga daging sapi di pasar Jawa Tengah dipengaruhi oleh harga daging sapi di pasar DKI Jakarta dari satu periode sebelumnya. Hal ini menandakan bahwa harga daging sapi di Pasar Semarang lebih cepat menyesuaikan terhadap perubahan harga di Pasar Jakarta. Adanya perbedaan waktu penyesuaian dalam jangka pendek antar pasar mengindikasikan adanya transmisi harga daging sapi yang cenderung asimetri.

Indikasi transmisi harga daging sapi yang asimetri antar pasar juga didukung oleh magnitude penyesuaian harga daging sapi yang berbeda antara pasar daging sapi Semarang dan Jakarta. Jika dilihat dari besaran koefisien parameternya, harga daging sapi di pasar Semarang memiliki pengaruh yang cukup besar terhadap harga daging sapi di pasar Jakarta, walaupun keduanya sama-sama bersifat inelastis. Hal ini ditunjukkan oleh nilai koefisien harga daging sapi di Pasar Semarang dua periode sebelumnya yang bernilai 0,113 dan harga daging sapi di Pasar Jakarta satu periode sebelumnya yang bernilai 0,093. Dengan demikian, jika terjadi perubahan harga di salah satu pasar sebesar $1 \%$, akan direspon dengan perubahan harga di pasar lainnya sebesar kurang dari $1 \% \quad(0,113$ dan 0,093).

\section{Hasil Estimasi VECM Pasar DKI Jakarta dan Jawa Timur}

Hasil estimasi model VECM, menunjukkan paling tidak terdapat satu persamaan yang mengalami kointegrasi pada integrasi pasar daging sapi Jakarta dan Surabaya.

\section{Tabel 10. Kointegrasi Jangka Panjang antar Pasar Daging Sapi Jakarta dan Jawa Timur}

\begin{tabular}{cccc}
\hline Persamaan & \multicolumn{3}{c}{ Variabel Harga } \\
\cline { 2 - 4 } Kointegrasi & PJKT & PSBY & C \\
\hline Kointegrasi 1 & 1.000 & -0.146 & -9.81 \\
& \multicolumn{3}{c}{$(0.115)$} \\
& \multicolumn{3}{c}{$[-1.268]$} \\
\hline
\end{tabular}

Ket: Angka dalam [ ] adalah nilai t-statistik; ${ }^{* *}=$ nyata pada taraf $1 \%$; ${ }^{* *}=$ nyata pada taraf $5 \%$; dan ${ }^{*}=$ nyata pada taraf $10 \%$. Nilai $\mathrm{t}$ tabel: $\mathrm{t}(\alpha=1 \%)=2.576, \mathrm{t}(\alpha=5 \%)=1.960$, $\mathrm{t}(\mathrm{a}=10 \%)=1.645$

Hasil estimasi mengindikasikan bahwa pergerakan harga daging sapi di Jakarta dalam jangka panjang tidak dipengaruhi secara signifikan oleh 
pergerakan harga daging sapi di Jawa Timur baik pada taraf kepercayaan 99\%, 95\% maupun 90\%.

Tabel 11 menunjukkan bahwa nilai ECM harga daging sapi di pasar DKI Jakarta signifikan $(p>0,01)$. Sementara itu, nilai ECM harga daging sapi di Pasar Surabaya tidak signifikan. Dengan demikian, hanya harga daging sapi di Pasar Jakarta yang dapat menyesuaikan menuju keseimbangan jangka panjang.

Nilai ECM pada harga pasar DKI Jakarta sebesar -0,035. Nilai ECM tersebut menunjukkan bahwa terdapat penyesuaian dari jangka pendek menuju jangka panjang sebesar -0,035 atau setiap bulan kesalahan dikoreksi sebesar -0,035 menuju keseimbangan jangka panjang.

Hasil estimasi model VECM pada Tabel 11 menunjukkan bahwa transmisi harga daging sapi di pasar pengecer Jakarta dipengaruhi secara signifikan ( $p>0,01)$ oleh harga daging sapi di pasar itu sendiri satu periode sebelumnya. Sementara itu, harga daging sapi di Pasar Surabaya dipengaruhi secara signifikan $(p>0,10)$ oleh harga daging sapi di pasar Jakarta satu periode sebelumnya. Hasil estimasi kointegrasi jangka pendek menunjukkan bahwa harga daging sapi di Pasar Jakarta dapat memengaruhi harga daging sapi di Pasar Surabaya dan tidak sebaliknya. Jakarta merupakan sentra konsumen sehingga pasar Jakarta seringkali menjadi acuan bagi pasar lainnya dalam menentukan harga. Menurut Zainuddin et al. (2015b), harga di pasar domestik daging sapi dicerminkan oleh harga daging sapi di Pasar Jakarta.

Tabel 11. Kointegrasi Jangka Pendek antara Pasar Daging Sapi Jakarta dan Jawa Timur

\begin{tabular}{lcc}
\hline $\begin{array}{c}\text { Error } \\
\text { Correction }\end{array}$ & $\mathrm{D}(\mathrm{PJKT})$ & $\mathrm{D}(\mathrm{PSBY})$ \\
\hline CointEq1 & $-0.035^{\star * *}$ & -0.003 \\
& $(0.007)$ & $(0.004)$ \\
& {$[-5.013]$} & {$[0.767]$} \\
D(PJKT(-1)) & $0.180^{* * *}$ & $0.030^{*}$ \\
& $(0.028)$ & $(0.018)$ \\
& {$[6.318]$} & {$[1.661]$} \\
D(PJKT(-2)) & 0.019 & -0.007 \\
& $(0.029)$ & $(0.018)$ \\
& {$[0.650]$} & {$[-0.410]$} \\
D(PSBY(-1)) & -0.033 & -0.006 \\
& $(0.044)$ & $(0.029)$ \\
& {$[0.728]$} & {$[-0.204]$} \\
& & \\
D(PSBY(-2)) & -0.004 & 0.001 \\
& $(0.045)$ & $(0.028)$ \\
& {$[-0.098]$} & {$[-0.046]$} \\
C & $-2.56 \mathrm{E}-05$ & $1.21 \mathrm{E}-05$ \\
& $(0.000)$ & $(8.7 \mathrm{E}-05)$ \\
& {$[0.186]$} & {$[0.138]$} \\
\hline
\end{tabular}

Ket: Angka dalam [ ] adalah nilai t-statistik; ${ }^{* * *}=$ nyata pada taraf $1 \%$; ${ }^{* *}=$ nyata pada taraf $5 \%$; dan ${ }^{*}=$ nyata pada taraf $10 \%$. Nilai $\mathrm{t}$ tabel: $\mathrm{t}(\alpha=1 \%)=2.576, \mathrm{t}(\alpha=5 \%)=1.960$, $\mathrm{t}(\alpha=10 \%)=1.645$

Pasar Surabaya walaupun merupakan sentra produsen daging sapi utama tidak dapat memengaruhi harga di pasar sentra konsumen utama karena ketersediaan atau suplai daging sapi di 
Pasar Jakarta tidak hanya dari Surabaya tetapi juga dari pasar impor. Adanya hubungan satu arah dalam transmisi harga daging sapi antara pasar Jakarta dan pasar Surabaya juga mengindikasikan adanya transmisi harga daging sapi yang cenderung asimetri.

\section{Implikasi Hasil}

Berdasarkan hasil analisis volatilitas harga di keempat kota di Pulau Jawa, harga daging sapi cenderung volatil dan persisten dalam jangka panjang hanya di Provinsi DKI Jakarta. Persistensi pada volatilitas harga daging sapi menunjukkan bahwa sekali harga daging sapi berfluktuasi, maka diperlukan waktu yang lama untuk bisa stabil kembali.

Hasil analisis volatilitas harga daging sapi di DKI Jakarta tersebut sama dengan hasil analisis volatilitas harga daging sapi yang dilakukan untuk tingkat nasional (Dewi et al, 2017 Komalawati et al., 2018). Hasil analisis tersebut membuktikan bahwa DKI Jakarta sebagai sentra konsumen memang menjadi pasar acuan bagi pasar daging sapi di Indonesia (Zainuddin et al., 2015a). Dengan demikian, upaya untuk mengantisipasi fluktuasi harga yang tidak menentu atau volatilitas dapat dilakukan dengan mengantisipasi volatilitas harga yang terjadi di Pasar DKI Jakarta.

Upaya antisipasi volatilitas harga di Pasar DKI Jakarta menjadi penting karena: (1) daging sapi merupakan salah satu komoditas penyumbang inflasi sehingga dikhawatirkan dapat memicu kenaikan atau inflasi volatilitas harga komodi lainnya seperti daging ayam, telur ayam, dan ikan (Prastowo et al, 2008); (2) ketidakpastian perubahan harga atau volatilitas dapat menyebabkan sulitnya pelaku usaha di industri pengolahan daging sapi seperti bakso untuk terus berproduksi (Kontan, 2013; DetikFinance, 2015; Berita Bojonegoro, 2015). Sementara itu, industri pengolahan daging sapi terutama UMKM usaha bakso menyebar dari kawasan perkotaan hingga ke pedesaan (Pulungan, 2014), sehingga berhentinya industri pengolahan daging sapi dapat berakibat pada meluasnya pengangguran; (3) volatilitas harga merupakan risiko harga yang harus diantisipasi oleh produsen karena menyebabkan ketidakpastian harga dan memengaruhi perencanaan produksi. Dengan melihat dampak dari volatilitas harga terhadap masyarakat secara luas, fokus dari kebijakan pengendalian harga sebaiknya diarahkan pada daerah-daerah dengan 
harga yang mengalami ketidakpastian perubahan harga atau volatilitas harga yang cenderung tinggi (Nuryati \& Rostiani, 2017).

Sebagai sentra konsumen, ketersediaan daging sapi di Pasar DKI Jakarta tidak hanya dari daging sapi lokal, tetapi juga dari impor. Dengan demikian, perubahan harga yang terjadi di Pasar DKI Jakarta dapat terjadi tidak hanya karena adanya permasalahan ketersediaan daging sapi lokal, tetapi juga akibat berbagai permasalahan terkait daging sapi impor. Hasil kajian Komalawati et al. (2018) menunjukkan bahwa impor sapi bakalan empat periode sebelumnya, stok periode sebelumnya, dan volatilitas nilai tukar merupakan beberapa faktor yang memengaruhi ketidakpastian dalam perubahan harga daging sapi di Indonesia. Dengan demikian, upaya untuk mengantisipasi gejolak harga yang terjadi di Pasar DKI Jakarta dapat dilakukan dengan membuat perencanaan ketersediaan daging sapi berdasarkan periode waktu.

Upaya pemenuhan ketersediaan jangka pendek atau sewaktu-waktu dapat dilakukan dengan impor daging sapi. Sementara itu, untuk pemenuhan stok jangka menengah, dapat dilakukan melalui pembesaran sapi bakalan impor dan lokal. Namun demikian, perlu juga dilakukan upaya agar tidak tergantung secara terus-menerus pada impor daging sapi dan sapi bakalan. Untuk itu, diperlukan upaya pemenuhan ketersediaan daging sapi jangka panjang dari sapi lokal. Hal tersebut dapat dilakukan melalui upaya pengembangan usaha pembesaran sapi lokal, perbibitan dan produksi sapi bakalan lokal. Upaya pengembangan usaha sapi dapat dilakukan dengan melakukan pendampingan pada petani sapi usaha kecil yang berupaya untuk menjadi peternak besar, memberikan fasilitas permodalan bagi petani sapi skala kecil agar dapat meningkatkan skala usahanya. Dengan terjaminnya ketersediaan daging sapi secara terusmenerus diharapkan harga daging sapi dapat tetap stabil.

Hasil kajian transmisi harga daging sapi antara sentra konsumen dan sentra produsen menunjukkan adanya indikasi transmisi harga yang cenderung asimetri antara harga di sentra konsumen DKI Jakarta dan harga di Pasar Jawa Barat, Jawa Tengah, dan Jawa Timur. Indikasi asimetri harga tersebut ditunjukkan oleh adanya perbedaan dalam kecepatan dan besaran penyesuaian harga menuju keseimbangan dalam jangka panjang, 
serta perbedaan pengaruh harga daging sapi dari sentra konsumen ke sentra produsen daging sapi.

Adanya asimetri transmisi harga daging sapi antara sentra konsumen dan sentra produsen dapat disebabkan oleh adanya biaya penyesuaian (adjustment cost atau menu cost), kekuatan pasar yang berbeda (market power), informasi pasar yang berbeda, dan kebijakan pemerintah (Meyer \& von Cramon-Taubadel, 2004).

Dalam kasus daging sapi, produsen daging sapi di Indonesia dikelompokkan menjadi kelompok peternak besar (feedlot), skala menengah, dan peternak rakyat (Pusat Kebijakan Perdagangan Luar Negeri, 2015). Banyaknya produsen daging sapi di Indonesia seharusnya dapat menyebabkan pasar menjadi kompetitif. Namun pada kenyataannya, peternak rakyat di Indonesia memiliki skala usaha yang relatif kecil dengan jumlah kepemilikan ternak satu hingga empat ekor dan biasanya berorientasi nonkomersial dan semi komersial (Risenasari, 2013). Dengan orientasi peternak rakyat yang non-komersial dan semi komersial, adanya perubahan harga tidak akan direspon dengan baik. Hal ini sesuai dengan hasil penelitian Zainuddin et al. (2015b) yang menunjukkan bahwa produsen atau peternak tidak responsif terhadap perubahan harga dengan nilai elastisitas penawaran daging sapi yang inelastis. Dengan demikian, produsen yang dimaksud pada kajian ini dan diperkirakan berorientasi komersial serta responsif terhadap perubahan harga hanya kelompok peternak besar (feedlot) dan skala menengah yang jumlahnya tidak banyak.

Dengan adanya penguasaan pasar oleh beberapa produsen di sentra produsen menyebabkan pasar menjadi tidak sempurna. Adanya asimetri transmisi harga dari pasar produsen ke pasar konsumen dapat menjadi indikasi adanya ketidaksempurnaan pasar di sentra konsumen dan sentra produsen.

Dengan adanya kekuatan pasar dapat dimiliki hanya oleh satu atau beberapa perusahaan saja, produsen atau pelaku pasar di sentra produsen dapat menjadi price makers atau penentu harga. Dengan demikian, tidak mengherankan jika respon perubahan harga lebih tinggi di pasar konsumen akibat adanya perubahan harga di pasar produsen daripada sebaliknya. Asimetri transmisi harga mengindikasikan bahwa produsen sapi dan pedagang pengecer dari Jawa Barat dan Jawa Tengah memiliki kekuatan pasar yang lebih 
tinggi daripada pedagang pengecer di wilayah Jakarta. Hal ini sesuai dengan hasil penelitian Hakim et al. (2020) yang menyatakan adanya ketidaksempurnaan pada pasar daging sapi akibat adanya beberapa pihak yang menguasai informasi pasar lebih baik dari pihak lainnya. Untuk itu, diperlukan upaya untuk memperbanyak produsen sapi skala besar agar pasar sapi atau daging sapi tidak dikuasai oleh beberapa perusahaan besar. $\mathrm{Hal}$ ini dapat dilakukan melalui: (1) kerja sama kemitraan perusahaan penggemukan dan peternak rakyat untuk pembiakan sapi bakalan dengan skala usaha per kelompok 100 ekor (Tawaf, 2018); (2) pemerintah perlu memfasilitasi berkembangnya usaha sapi potong dari peternak rakyat dengan memberikan kemudahan kredit dan bunga bank yang cukup ringan dengan tempo waktu pembayaran hutang yang tidak terlalu lama; (3) pengembangan kelembagaan kawasan pertanian berbasis korporasi untuk usaha perbibitan atau penggemukan sapi potong secara berkelompok dengan sistem manajemen yang profesional. Pengembangan kelembagaan sapi potong berbasis korporasi seperti yang sedang diupayakan oleh pemerintah melalui Kementerian Pertanian merupakan salah satu upaya untuk meningkatkan skala usaha peternak kecil. Pengembangan kawasan pertanian berbasis korporasi petani sebagaimana tercantum dalam Peraturan Menteri Pertanian Republik Indonesia Nomor 18/PERMENTAN/RC.040/4/2018 yang bertujuan untuk memperkuat sistem usaha ternak secara utuh dalam satu manajemen kawasan seperti yang dilaksanakan di kawasan ternak kambing Senduro di Kecamatan Senduro, Kabupaten Lumajang (Soetriono et al., 2020).

\section{KESIMPULAN DAN REKOMENDASI KEBIJAKAN}

Hasil analisis volatilitas harga daging sapi di keempat kota menunjukkan bahwa volatilitas harga daging sapi di DKI Jakarta yang cenderung volatil dan persisten dalam jangka panjang. Hasil analisis ini memperkuat dugaan bahwa pasar daging sapi DKI Jakarta menjadi pasar acuan harga bagi pasar lainnya. Dengan demikian, upaya stabilisasi harga daging sapi dapat difokuskan di pasar DKI Jakarta sebagai pasar acuan harga nasional. Upaya stabilisasi harga daging sapi dapat dilakukan dengan menjaga ketersediaan daging sapi dari impor daging sapi (jangka pendek), 
impor sapi bakalan (jangka menengah), dan upaya mempersiapkan ketersediaan bibit sapi lokal dan sapi potong lokal (jangka panjang).

Transmisi harga daging sapi antara sentra konsumen DKI Jakarta dan sentra produsen Jawa Barat, Jawa Tengah, dan Jawa Timur menunjukkan transmisi harga daging sapi yang cenderung asimetri. Salah satu penyebab dari asimetri transmisi harga daging sapi antara pasar DKI Jakarta dan Jawa Barat, Jawa Tengah, dan Jawa Timur disebabkan oleh adanya dugaan penguasaan pasar daging sapi oleh beberapa perusahaan besar di Jawa Barat dan Jawa Tengah. Untuk itu diperlukan upaya untuk meningkatkan jumlah peternak sapi yang memiliki skala usaha yang besar agar terjadi iklim usaha daging sapi yang semakin kompetitif.

Hal ini dapat dilakukan melalui: (1) kerja sama kemitraan perusahaan penggemukan dan peternak rakyat untuk pembiakan sapi bakalan; (2) pemerintah memfasilitasi berkembangnya usaha sapi potong dari peternak rakyat dengan memberikan kemudahan kredit dan bunga bank yang cukup ringan dengan tempo waktu pembayaran hutang yang tidak terlalu lama; (3) pengembangan kelembagaan kawasan pertanian berbasis korporasi untuk usaha perbibitan atau penggemukan sapi potong secara berkelompok dengan sistem manajemen yang profesional.

\section{UCAPAN TERIMAKASIH}

Ucapan terima kasih diberikan kepada SEARCA sebagai pemberi beasiswa, sehingga penelitian ini dapat berjalan dengan baik. Ucapan terima kasih juga diberikan kepada Kementerian Perdagangan khususnya Badan Pengkajian dan Pengembangan Perdagangan.

\section{DAFTAR PUSTAKA}

Badan Pusat Statistik (BPS). (2020). Pengeluaran untuk Konsumsi Penduduk Indonesia per Provinsi: Berdasarkan Hasil Susenas Maret 2020. Jakarta: Badan Pusat Statistik.

Berita Bojonegoro. (2015, August 24). Pedagang Bakso Keluhkan Naiknya Harga Daging Sapi. https://beritabojonegoro.com/read/42 6-pedagang-bakso-keluhkannaiknya-harga-daging-sapi.html

Burhani, F. J., \& Fariyanti, A. (2013). Analisis Volatilitas Harga Daging Sapi Potong Dan Daging Ayam Broiler Di Indonesia. Forum Agribisnis: Agribusiness Forum, Vol 3(2), pp. 129-146.

Ceballos, F., Hernandez, M. A., Minot, N., \& Robles, M. (2016). Transmission of Food Price Volatility from International to Domestic Markets: Evidence from Africa, Latin America, and South Asia. Dalam M. Kalkuhl, von B. Joachim, \& M. Torero (Eds.). Food Price Volatility and Its Implications for Food Security and Policy (p. 620). Switzerland: Springer International Publishing. 
DetikFinance (2015, August 23). Harga Daging Sapi Melambung, Penjualan Bakso Anjlok $80 \%$. Diunduh tanggal 10 Maret 2020 dari https://finance.detik.com/beritaekonomi-bisnis/d-2998693/hargadaging-sapi-melambung-penjualanbakso-anjlok-80

Dewi, I., Nurmalina, R., Adhi, A.K., Brummer, B. (2017). Price Volatility Analysis in Indonesian Beef Market. Makalah disajikan pada $2^{\text {nd }}$ International Conference on Sustainable Agriculture and Food Security: A Comprehensive Approach pada tanggal 12-12 Oktober 2015 di Universitas Padjajaran, Bandung.

Firmansyah, Afriani, H., Paiso, W.A. (2021). Analisis Volatilitas Harga Daging Sapi Sebelum Sampai Dan Sesudah Hari besar Agama di Kota Jambi. Jurnal Ilmiah Universitas Batanghari Jambi, Vol. 21(1), pp. 365-371.

Hakim, D.B., Komalawati, \& Difah, D.A. (2020). Estimating Asymmetric Price Transmission in the Indonesian Beef Market. J.ISSAAS, Vol. 26(2), pp. 4253

Juanda, B. \& Junaidi. (2012). Ekonometrika Deret Waktu: Teori \& Aplikasi. Bogor: IPB Press.

Komalawati, K., Asmarantaka, R. W., Nurmalina, R., \& Hakim, D. B. (2018). Dampak Volatilitas Harga Daging Sapi terhadap Industri Pengolahan Daging Sapi Skala Mikro di Indonesia. Pangan, Vol. 27(1 April 2018), pp. 922.

Komalawati, Asmarantaka, R. W., Nurmalina, R., \& Hakim, D. B. (2019). Modeling price volatility and supply response of Beef in Indonesia. Tropical Animal Science Journal, Vol.42(2), pp. 159-166.

Kontan. (2013, January 23). Kenaikan harga daging sapi tekan penjual bakso. Diunduh tanggal 10 Maret 2020 dari https://industri.kontan.co.id/news/ken aikan-harga-daging-sapi-tekan- penjual-bakso.

Kusriatmi. (2014). Dampak Kebijakan Swasembada Daging Sapi terhadap Kinerja Ekonomi Subsektor Peternakan di Indonesia. Disertasi. Bogor: Sekolah Pascasarjana Institut Pertanian Bogor.

Meyer, J., \& von Cramon-Taubadel, S. (2004). Asymmetric price transmission: A survey. Journal of Agricultural Economics, Vol. 55(3), pp. 581-611.

Miftahuljanah, Sukiyono, K., Asriani, P.S. (2020). Volatilitas dan Transmisi Harga Cabai Merah Keriting Pada Pasar Vertikal Di Provinsi Bengkulu. Jurnal Agro Ekonomi, Vol. 38(1), pp. 29-39.

Nicholson, W. (1995). Mikroekonomi Intermediate dan Aplikasinya: Terjemahan dari Intermediate Microeconomics. Jakarta: Binarupa Aksara.

Nuryati, Y., \& Rostiani, M. (2017). Upaya Stabilisasi Harga Daging Sapi. Badan Pengkajian Dan Pengembangan Kebijakan Perdagangan Kemendagri, Vol. V(03), pp. 13-16.

Pagala, M.A.Y., Hadayani, Kalaba, Y. (2017). Analisis Struktur Bawang Merah Varietas Lembah Palu di Kabupaten Sigi. J. Agroland, Vol. 24(2), pp.128-137.

Pipit, Pranoto, Y.S., Evahelda. (2019). Analisis Volatilitas Harga Daging Sapi di Provinsi Kepulauan Bangka Belitung. Jurnal Ekonomi Pertanian dan Agribisnis (JEPA), Vol. 3(3), pp. 619-630.

Prastowo, N. J., Yanuarti, T., \& Depari, Y. (2008). Working Paper: Pengaruh Distribusi Dalam Pembentukan Harga Komoditas dan Implikasinya Terhadap Inflasi. Jakarta: Bank Indonesia.

Pulungan, R. E. (2014). Dampak Kebijakan Indonesia Membatasi Kuota Impor Daging Sapi dari Australia. JOM FISIP, Vol. 1(2), pp. 1-10. 
Pusat Data dan Sistem Informasi Pertanian. (2020). Buku Outlook Komoditas Peternakan Daging Sapi. Jakarta: Pusat Data dan Sistem Informasi Pertanian Sekretariat Jenderal Kementan.

Pusat Kebijakan Perdagangan Luar Negeri. (2015). Kajian Efektivitas Kebijakan Impor Produk Pangan Dalam Rangka Stabilisasi Harga. Diunduh tanggal 8 Juni 2017 dari http://bppp.kemendag.go.id/media_c ontent/2017/08/Kajian Efektivitas Ke bijakan_Impor_Produk_Pangan_dala m_Rangka_Stabilisasi_Harga.pdf

Risenasari, H. (2013). Analisis Peranan Kemitraan terhadap Rantai Nilai Sapi Potong Peternakan Rakyat di Kabupaten Banjarnegara, Provinsi Jawa Tengah. Tesis. Bogor: Sekolah Pascasarjana Institut Pertanian Bogor.

Rusdiana, S. \& Maesya, A. (2017). Pertumbuhan Ekonomi dan Kebutuhan Pangan di Indonesia. Agriekonomika, Vol. 6(1): pp. 12-25.

Sahara, Utari, M.H., Azijah, Z. (2019). Volatilitas Harga Bawang Merah di Indonesia. Buletin Ilmiah Litbang Perdagangan, Vol. 13(2), pp. 309336.

Septiyarini, D., Sahbudin, Sulaiman, S.H., Yurisinthae, E. (2020). Integrasi Pasar Daging Sapi menggunakan Metode Vector Error Correction Model (VECM). Jurnal Riset Agribisnis dan Peternakan, Vol. 5(2), pp. 60-72.

Simatupang, P. (1999). Industrialisasi Pertanian sebagai Strategi Agribisnis dan Pembangunan Pertanian. Bogor: Pusat Penelitian Sosial Ekonomi.
Soetriono, S., Hapsari, T.D., Muhlis, A. (2020). Pemodelan Usaha Ternak Kambing Senduro menuju Penguatan Kelembagaan Korporasi di Kabupaten Lumajang. Livestock and Animal Research, Vol. 18(3), pp. 229239.

Sukmawati D. (2017). Pembentukan harga cabai merah keriting (Capsicum annum L) dengan analisis harga komoditas di sentra produksi dan pasar induk (studi kasus pada sentra produksi cabai merah keriting di Kecamatan Cikajang, pasar induk Gedebage, pasar induk Caringin dan pasar induk Kramat Jati). Mimbar Agribisnis, Vol. 1(1), pp. 79-84.

Tawaf, R. (2018) Usaha Pembiakan Sapi Potong Pola Kemitraan antara Korporasi dengan Peternak Rakyat. Jurnal IImu-IImu Sosial dan Humaniora, Vol. 20(1), pp. 45-56.

Yusufadisyukur, E.O., von CramonTaubadel, S., Suharno, Nurmalina, R. (2020). Market Integration and Price Transmission of Beef in the Archipelagic State: The Case of the Provinces in Indonesia. Jurnal Manajemen \& Agribisnis, Vol. 17(3), pp. 265-273.

Zainuddin, A., Asmarantaka, R.W., \& Harianto. (2015a). Integrasi Harga Daging Sapi di Pasar Domestik dan Internasional. Buletin IImiah Litbang Perdagangan, Vol. 9(2), pp. 1-10.

Zainuddin, A., Asmarantaka, R.W., \& Harianto. (2015b). Perilaku Penawaran Peternak Sapi di Indonesia dalam Merespon Perubahan Harga. Jurnal Agribisnis Indonesia, Vol. 3(1), pp. 1-10. 
